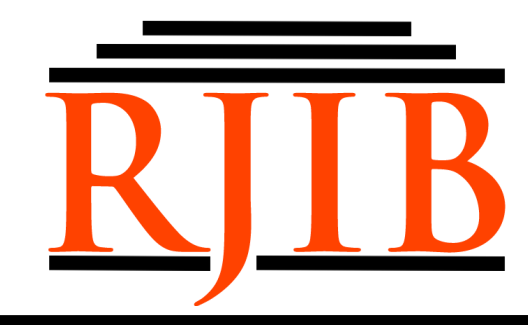

RETORIKA: Jurnal Ilmu Bahasa

Vol. 5, No. 2 Oktober 2019, Page 114-121

\title{
Diagnostic Assessment to Analyse Learning Style of Students of Travel Business Management Program in Sekolah Tinggi Pariwisata Bali
}

\author{
Desak Gede Chandra Widayanthi* and Putu Irmayanti Wiyasa
}

Universitas Udayana, Bali, Indonesia

chandrawidaa@gmail.com

\begin{tabular}{|l|l|}
\hline Received: 20/05/2019 & Revised: 10/10/2019 \\
\hline How to cite (in APA style): & \\
Widayanthi, D, G, C., Wiyasa, P, I. (2019). Diagnostic Assessment to Analyse Learning Style of Students of \\
Travel Business Management Program in Sekolah Tinggi Pariwisata Bali. RETORIKA: Jurnal Ilmu \\
Bahasa, 5(2), 114-121. doi: http://dx.doi.org/10.22225/jr.5.2.1113.114-121 \\
\hline
\end{tabular}

\begin{abstract}
To understand the learning style of the learners is important and useful to decide what learning strategy is the most suitable to be implemented. Considering that significance, this study aims at analysing learning style of students of Travel Business Management, Sekolah Tinggi Pariwisata Bali (Bali Tourism Institute). The data was collected through questionaire in which the contentc is the adaptation of VARK questionaire which was developed by Flemming (1993, in Pritchard, 2009). Data was analysed quantitatively through tabulation and then described qualitatively. As the result, the students are found to have different learning styles, namely 6 students $(20,69 \%)$ are aural, 5 students $(17,24 \%)$ have read/write learning style, 15 students $(51,72 \%)$ are kinaesthetic, and 1 students to each has bimodal kinaesthetic Read/write-kinaesthetic, bimodal aural-kinaesthetic, and trimodal visual-aural-read/write. Based on the result, it can be proposed a recommendation to the teacher that the strategies of teaching have to facilitate all the learning styles own by the students to make them able to learn at their best.
\end{abstract}

Keywords: Diagnostic Assessment; learning style; VARK System

\section{INTRODUCTION}

Classroom situation is very dynamic. This is caused by the unique character own by each student which is could not be avoided. In certain learning material or activity, some of the students could finish it soon or very fast, while the other could finish it only if the teachers explain the material more. Some of the students could love learning through game, while the other find it boring or overhelming. If the teachers understand these differences, there will be appropriate anticipated acts being planned. It is because the understanding that every students has their own unique character will help teacher to plan complex learning activities that can facilitate all the uniqueness.
In order to conduct high quality and successful learning process that could impact the learners positively, teachers have to understand the needs of the learners and facilitate the need to achieve the optimum learning success. According to (Pritchard, 2009), all individual learners have their own preference in working, thinking, and learning. If the preference is not facilitated or not being taken into account by forcing the learning into one fix strategy, the learning success will not be achieved effectively.

The preference of learning is called as learning style (Pritchard, 2009). Learning style as the way of an individual to learn and their preference in way of learning to enhance their best ability to think, comprehend information, demonstrate the result of learning and obtaining 
knowledge and skills (Pritchard, 2009). Moreover, (Reid, 2005) stated that learning style could be also impacted by the culture of the learners, classroom and school situation, teaching style, classroom dynamics and curriculum. Learning preference, according to (Pritchard, 2009), can be illustrated through picture and text; group and individual work; and structured and unstructured learning. Learning style is not only related to physical environment, but also to emotional and psychological environment (Dunn, Beaudry, \& Klavas, 1989).

Taking the learning style profile of the

Table 1.

Classification of Learning Style (Pritchard, 2009)

\begin{tabular}{|c|c|}
\hline \multicolumn{2}{|c|}{ Learning Style Classification } \\
\hline Model Honey-Mumford & $\begin{array}{l}\text { Activists, Reflectors, Theorists, and } \\
\text { Pragmatists. }\end{array}$ \\
\hline $\begin{array}{l}\text { Neuro-Linguistic Pro- } \\
\text { gramming (NLP) }\end{array}$ & Visual, Aural and Kinaesthetic. \\
\hline VARK System & $\begin{array}{l}\text { Visual, Aural, Read/Write, and } \\
\text { Kinaesthetic }\end{array}$ \\
\hline
\end{tabular}

On the classification of learning style from Honey-Mumford, learning style is classified into four categories, such as Activists, Reflectors, Theorists, and Pragmatists. Activists tend to learn best by doing it practically (learning by doing) and the learning will not be effective through only reading books. Activist like to learn in group activities and will easily get bored to repetition. Reflectors like observing activities and obtaining much data before deciding something. Thus, Reflectors learn through examples and detail imaging. Theorists thing logically and sistematically. They learn best through problem solving activities and one-step -at-a-time approach. Pragmatists are always looking for prove. Learners with this learning style will always challenge the knowledge they get to understand it better. All the four learning styles in Honey-Mumford Model is basically devide learning style into active, reflective, theoretic, and pratical.

Based on the way to communicate and the implication to the learning process, NeuroLinguistic Programming (NLP) Model classifies learning style into three categories, such as Visual, Aural and Kinaesthetic. Visual learners learn a lot through visual senses, thus the learning material is best presented in form of diagram, map, poster and model displays. Aural learner learn best through hearing senses, thus aural learners will learn best through discussion activities, listening to explanation, learners into account is important and useful to decide the teaching strategy which will be impelented in the learning process. Teachers who understand their students' learning style could encourage their students to be actively participating in the classroom in their own style, since the teachers have facilutated all students' needs based on their unique learning styles.

Learning style, furthermore, is classified differently of different experts (Pritchard, 2009). Those classifications are summarized in Table 1. Kinaesthetic

interview, and listening to audio record. Kinaesthetic learners learn best through active activity (learn by doing). This type of learner learn better through practice, field trip, moving things and other practical ways.

As development of NLP Model, Fleming (2001) in (Pritchard, 2009) added type of learning style read/Write. These developed model is known as VARK System. VARK itself is the acronym of Visual, Aural, Read/ Write, Kinaesthetic. As an additional type to NLP Model, Read/Write is a learning style that the learners of this type learn best through reading text and writing summary of what they have read, listened, and seen. Other than that, in VARK System there is a type of learning style known as multimodal learning style (Shah, Shenoy, \& Srikant N, 2013). Multimodal learners can be best learn through more than one learning styles and re-classified as bimodal, trimodal, and even quadmodal.

Some previous studies have been undergone, one of the studies was to identify and prepare information about students' major perceptual learning style preferences and minor learning preferences (Jamulia, 2018), another study (Arifin, 2015) was to identify learning style preferences of the students at SMPN 1 Dagangan Madiun and their implication to English teaching, and other related studies were to find out students' learning style and strategies used students who have visual, auditory, and kinesthetic learners in English 
Speaking (Yuliani, 2012). Considering those studies aforementioned, this study is furthermore designed to analyze the learning style of students in Travel Business Management Program, Sekolah Tinggi Pariwisata Bali (Bali Tourism Institute). As it mentioned above, there are classifications of learning style such as Model Honey-Mumford, Neuro-Linguistic Programming (NLP), and VARK System. However, in this study, it limited on the VARK Questionaire developed by Flemming (1993) in (Pritchard, 2009)

\section{METHODS}

(Nurgiyantoro, 2004) stated that assessment can be defined as giving consideration or grading, valuing, value judgement which is in education means considering the students' learning result, teaching strategy, learning activity, curriculum or other educational program. Assessment could be in the form of diagnostic assessement, which means data collection to analyse strengths and weaknesses of the students to be used as reference in planning further learning activities.

Oner of diagnostic assessment instrument is VARK questionaire, which aims at obtaining information about learners' learning style profile through objective test. (Flemming, 2018) proposed four modalities which reflect someone's learnign experience. VARK questionaire consists of 16 questions which will make the users able to know type of their learning style. VARK questionaire tests visual, aural, kinaesthetic-perseptual, and also tests visual/tactil which is by Fleming called
Read/Write mode. Questions in the form of multiple chice tests of which each item reflects each modality. Users could choose one of the answer choices that is considered as the most appropriate act to represent the decision that the users would choose in certain situation. The type of learning styles that get the highest score are more than one style, it can be analysed as multimodal learning style.

\section{III.RESULT AND DISCUSSIONS}

Analysis of learning style of Students D4 majoring in Travel Business Management (MBP) Bali Tourism College (STP) is carried out using a VARK questionnaire developed by Flemming. This questionnaire was chosen because the data can be analyzed by simple tabulation and consisted of 16 simple questions so that it is efficient in terms of data collection. In addition, according to Flemming (2018) global research has been conducted towards the use of VARK questionnaires to determine the reliability of test instruments. Through this research, the reliability, Aural, Read / Write, and Kinaesthetic sub-scales index reached 0.85, $0.82,0.84$ and 0.77 respectively which meant that all sub-scales in the VARK questionnaire were reliable.

The questionnaire instrument used in this study was an adaptation of the VARK Questionnaire on the official Flemming website (vark-learn.com). The questionnaire consisted of 16 question items with four multiple choices that reflect the respective learning style. The reflection of the learning style in each multiple choice item is presented in Table 2, and the questionnaire is presented in Appendix 1.

Table 2

Type of Learning Style Reflected on the Instrument

\begin{tabular}{|c|c|c|c|c|c|}
\hline \multirow[t]{2}{*}{ Number tem } & \multicolumn{4}{|c|}{ Options } & \\
\hline & $\mathrm{A}$ & $\mathrm{B}$ & $\mathrm{C}$ & $\bar{D}$ & \\
\hline 1 & $\mathrm{~K}$ & A & $\mathrm{R}$ & $\mathrm{V}$ & \\
\hline 2 & $\mathrm{~V}$ & A & $\mathrm{R}$ & $\mathrm{K}$ & \\
\hline 3 & $\mathrm{~K}$ & $\mathrm{~V}$ & $\mathrm{R}$ & A & \\
\hline 4 & $\mathrm{~K}$ & A & V & $\mathrm{R}$ & \\
\hline 5 & A & V & $\mathrm{K}$ & $\mathrm{R}$ & \\
\hline 6 & K & $\mathrm{R}$ & V & A & \\
\hline 7 & $\mathrm{~K}$ & A & V & $\mathrm{R}$ & \\
\hline 8 & $\mathrm{R}$ & $\mathrm{K}$ & A & $\mathrm{V}$ & \\
\hline 9 & $\mathrm{R}$ & K & A & V & \\
\hline 10 & $\mathrm{~K}$ & V & $\mathrm{R}$ & A & \\
\hline 11 & V & $\mathrm{R}$ & A & $\mathrm{K}$ & Note: \\
\hline 12 & A & $\mathrm{R}$ & V & $\mathrm{K}$ & $\mathrm{V}=\mathrm{Visual}$ \\
\hline 13 & K & A & $\mathrm{R}$ & $\mathrm{V}$ & $A=$ Aural \\
\hline 14 & K & $\mathrm{R}$ & A & $\mathrm{V}$ & A = Aural \\
\hline 15 & $\mathrm{~K}$ & A & $\mathrm{R}$ & V & $\mathrm{R}=\mathrm{Read} /$ Write \\
\hline 16 & $\mathrm{~V}$ & A & $\mathrm{R}$ & $\mathrm{K}$ & $\mathrm{K}=$ Kinaesthetic \\
\hline
\end{tabular}


The questionnaire was then translated into Indonesian and developed in the form of an online questionnaire using Google form application. Links of the questionnaire are sent to students to be responded. The number of students who answered the test were 29 students of D4 MBP Study Program. Each respondent's name was disguised as the initial of R01 for the First Respondent, up to R29 for the 29th Respondent.

The results of the analysis were analyzed by simple tabulations based on a reflection of the learning style in each multiple choice item. The results of the complete tabulation are presented in Appendix 2, while the summary of the tabulation results is presented in Table 3.

Table 3

Summary of Tabulation Result

\begin{tabular}{ccc}
\hline VISUAL & $\mathbf{0}$ & $\mathbf{0 . 0 0 \%}$ \\
\hline AURAL & 6 & $20.69 \%$ \\
READ/WRITE & 5 & $17.24 \%$ \\
KINESTHETIC & 15 & $51.72 \%$ \\
BIMODAL (RK) & 1 & $3.45 \%$ \\
BIMODAL (AK) & 1 & $3.45 \%$ \\
TRIMODAL (VAR) & 1 & $0.34 \%$ \\
TOTAL & 29 & $100 \%$
\end{tabular}

According to the results of the VARK questionnaire answer analysis, it is showed that 6 respondents $(20.69 \%)$ had "aural" learning style, 5 people $(17.24 \%)$ had a learning style of "read / write", 15 people $(51.72 \%)$ had "kinaesthetic" learning style, and for "bimodal Read / write-kinaesthetic" , "bimodal auralkinaesthetic", and "trimodal visual-aural-read / write" learning style are respectively chosen by 1 student.

\section{Learning-Implementation Recomendation}

Table 4

The characteristics of learning style of VARK System

\begin{tabular}{cc}
\hline $\begin{array}{c}\text { LEARNING } \\
\text { STYLE Type }\end{array}$ & Characteristics \\
\hline Visual & $\begin{array}{c}\text { Optimally gaining information by using visual aids for } \\
\text { instance map, diagram concept, graphic, flow chart, arrow } \\
\text { symbol, round, hierarchical, etc. } \\
\text { Aural }\end{array}$ \\
Effectively learning by discussion, listening to particular \\
talks, radio, and web chat and information would be com- \\
prehended better through informal language. \\
Optimally learnt through reading text, powerpoint presen- \\
tation, jotting down list, note, using dictionary and cita- \\
tion. \\
Kinaesthetic \\
$\begin{array}{c}\text { Thoroughly link with the terms "learning by doing." It is } \\
\text { optimally works by practicing by doing simulation using } \\
\text { media of video, film, case study, theory, and field study }\end{array}$
\end{tabular}

In addition, learning styles with multimodal types will be able to learn optimally through more than one way, either alternately according to the situation or simultaneously.

Basically, the instructor should facilitate all types of learning styles in learning. However, the learning style profile can be a
Based on the results of the analysis of the answers towards the VARK questionnaire, it can be showed that the majority of the students' respond are kinaesthetic learning style which was resulted $51.72 \%$. In preparing recommendations related to teaching strategies and learning strategies, it is necessary to know the character of each learning style in advanced. The learning style character according to the VARK System based on Flemming (2018) is presented in Table 4. 

studies.

Facilitate field trip activities and case

Use project-based learning, communicative learning methods, and other methods that support "learning by doing."

Support aural learning style by holding group discussions, clarifying voices in material explanations, and providing opportunities to ask questions.

Balance learning by giving text books or modules, explanation pointers, and opportunities to take notes.

By knowing the learning style is not merely useful for the teacher, but also for the students. It is recommended for the instructor to give the results of the learning style analysis and explain the learning strategies that are suitable for each learning style. It is important to encourage self-learning and student-centered learning. The suggested learning strategies for each learning style are presented in Table 5.

Table 5

Recommended learning strategy in accordance with the learning style

\begin{tabular}{|c|c|}
\hline LEARNING STYLE Type & Recommended Learning Style \\
\hline Visual & Using illustration, picture, colours, and map \\
\hline \multirow{8}{*}{ Aural } & Exchanging the words into visual aids \\
\hline & Using Flow chart, diagram, and coloured graphic \\
\hline & Using highlighter \\
\hline & $\begin{array}{l}\text { Using coloured pen } \\
\text { Memorizing by reading aloud and using mne- } \\
\text { monic }\end{array}$ \\
\hline & $\begin{array}{c}\text { Attending the class regularly to listen to teacher's } \\
\text { explanation. }\end{array}$ \\
\hline & $\begin{array}{c}\text { Asking friends to read aloud so that they also can } \\
\text { learn simultaneously. }\end{array}$ \\
\hline & $\begin{array}{c}\text { Recording own voices to replay it during the } \\
\text { learning process. }\end{array}$ \\
\hline & $\begin{array}{c}\text { Instead of taking a note, it is better to record the } \\
\text { teacher's explanation }\end{array}$ \\
\hline \multirow[t]{6}{*}{ Read/Write } & $\begin{array}{l}\text { Maximizing the discussion } \\
\text { Using mnemonic to memorize the learning }\end{array}$ \\
\hline & Making list \\
\hline & Using dictionary or book sources \\
\hline & Taking a note in details \\
\hline & $\begin{array}{c}\text { Memorizing and re-writing using their own } \\
\text { words }\end{array}$ \\
\hline & $\begin{array}{c}\text { Expressing their idea through handwritings on } \\
\text { their notebook. }\end{array}$ \\
\hline \multirow[t]{7}{*}{ Kinaesthetic } & $\begin{array}{l}\text { Menggunakan singkatan/mnemonics untuk } \\
\text { menghapal materi. } \\
\text { Learning by touching the media by holding media } \\
\text { such as flash card, etc. }\end{array}$ \\
\hline & Finding the real example \\
\hline & Doing simple body movement to avoid boredom \\
\hline & Doing roleplay \\
\hline & $\begin{array}{l}\text { Learning while doing simple exercising like do- } \\
\text { ing or push up. }\end{array}$ \\
\hline & Maximizing the practical learning \\
\hline & Doing field trips. \\
\hline
\end{tabular}




\section{IV.CONCLUSION}

According to the findings and discussions, it can be concluded as follows.

D4 MBP Study Program students have different learning style namely 6 respondents $(20.69 \%)$ have aural learning style, 5 people $(17.24 \%)$ have learning style read / write, 15 people $(51,72 \%)$ have a kinaesthetic learning style, each one has a bimodal Read / writekinaesthetic learning style, bimodal auralkinaesthetic, and trimodal visual-aural-readwrite.

Based on a learning style analysis, recommendations can be made to the instructor regarding teaching strategies that can be done in the classroom to facilitate the needs of students based on the learning style profile. In addition, recommendations are also given to students related to learning strategies that are compatible with their respective learning styles.

\section{REFERENCE}

Arifin, Z. (2015). Analyzing The Learning Styles Of Junior High School Students And The Implication To English Teaching: A Case Study At Smpn I Dagangan Madiun. Jurnal Penelitian Humaniora, 16(1), 48-54.

Dunn, R., Beaudry, J., \& Klavas, A. (1989). Survey of research on learning styles. Educational Leadership. California Journal of Science Education, 75-98.

Flemming, N. (2018). VARK: A Guide to Learning Style. Retrieved from http// www.varklearn.com/english/page.asp? $\mathrm{p}=$ questionnaire.

Jamulia, J. (2018). Identifying Students Learning Style Preferences At Iain Ternate. International Journal of Educational Universitas Pendidikan Indonesia, 10(2), 121-129. Retrieved from http:// dx.doi.org/10.17509/ije.v10i2.1631

Nurgiyantoro, B. (2004). Statistik Terapan untuk Penelitian Ilmu-ilmu. Sosial. Yogyakarta: Gadjah Mada University Press.

Pritchard, A. (2009). Ways of Learning: Learning Theories and Learning Styles in the Classroom. New York: Routledge.

Reid, G. (2005). Learning Styles and Inclusion. London: Paul Chapman Publishing.

Shah, J. A. K., Shenoy, N., \& Srikant N. (2013). How different are students and their learning styles? International Journal of Research in Medical Sciences, 1(3), 212-215. Retrieved from http://citeseerx.ist.psu.edu/viewdoc/ download?

doi $=10.1 .1 .1033 .1385 \&$ rep $=$ rep $1 \&$ type $=$ pdf

Yuliani, H. (2012). An analysis of students Vak Learning Styles and strategies in English speaking of second grade at SMA Unggalan Sidoarjo. Semantic Scholar. Retrieved from https://www.semanticscholar.org/paper/Ananalysis-of-students-Vak-Learning-Stylesand-in-Yuliani/ dd5489bb702713d1974bf20935656c6dcabc0 456

\section{Appendix}

\section{VARK QUESTIONNAIRE}

In order to analyse the students' learning style, the questionnaire is administered towards 29 respondents. 16 questions are used on the questionnaire with different point and intention for respective question. The questions that are used on the questionnaire is as follows.

1. You are helping someone who asks for directions to the airport. At that time you don't have any activity. What will you do?

a. Guide the person by accompanying him to the airport.

b. Explain the direction of the road orally.

c. Write down the description of direction.

d. Describe a map to help him get to the airport.

2. You suddenly doubt the correct spelling is the Pharmacy or Pharmacy. What will you do?

a. Continue to think of the two spellings in your mind then choose one.

b. Say the two spellings and then choose one based on the sound that you think is most appropriate.

c. Look at the dictionary.

d. Write down the two spellings then choose one.

3. You are appointed as your class vacation coordinator. You want to get input / feedback from your friends about the itinerary that you have compiled. What will you do?

a. Explain in short bulletins verbally.

b. Describe your plan in maps, diagrams and charts.

c. Print a complete itinerary and share it with friends.

d. Call, send an email and send a text message related to the itinerary.

4. You are cooking special dishes for your family. 
What will you do?

a. Cooking dishes that you only know so there is no need to look at recipes.

b. Ask friends about what you should cook and the recipe.

c. Look through recipe books or recipes online and decide based on the picture that you think is the best and tantalizing

d. Look through the recipe book or recipe online and decide to find the dish you know.

5. Some tourists want to know about nature conservation near where you live. You happen to meet them on the road and you are not in any activity. They ask you questions. What will you do?

a. Explain about nature conservation in a verbal and detailed manner.

b. Doing an internet search then explains while showing the online images that you find as an illustration.

c. Go with them to nature conservation while explaining.

d. Search online and send them a link to the description of nature conservation.

6. You will buy a new smart phone. Apart from price, what most influences your decision on choosing a smart phone that you will buy?

a. Experience after trying to use it.

b. Read the feature details to a trusted source.

c. Product design and appearance.

d. Oral explanation from product sales person.

7. You understand the fastest when ...

a. See the demonstration / demonstration.

b. Hearing oral explanations then asking questions.

c. See exposure through charts and graphs.

d. Read instructions / manuals / textbooks.

8. You experience knee joint problems with unusual conditions. To understand the condition, what will you do?

a. Ask the doctor to provide an online reference or summary of details that you can read about your condition.

b. Ask the doctor to explain using miniature bone and joint structures.

c. Asking the doctor to explain it verbally in detail. d. Ask the doctor to explain using a simple schematic diagram or image.

9. You want to learn new applications or new games on your computer. what will you do?

a. Read instructions in the application and game.

b. Ask a friend.

c. Trial randomly pressing menu / keyboard.

d. Look for written sources that explain simple diagrams or schemes.

10. What website do you like the most?

a. Which has many features that you can try to click.

b. The design is attractive.

c. Which has a clear explanation and description.

d. Which has audio features.

11. You want to buy a Non-Fiction book. Besides price, what affects you the most to buy it?

a. Attractive cover and graphic design.

b. Experience reading the contents at a glance.

c. Recommendation friend.

d. Its contents are in the form of real stories, experiences, and examples of application.

12. You are reading a website about tips and how to take good photos using the camera you just bought. What do you expect most from the website?

a. The opportunity to contact customer service or website admin to ask about tips and methods directly.

b. Clear written explanations with lists and pointers.

c. Written explanation with schematic diagrams and drawings.

d. Illustration of use that contains photos of someone using the program and examples of good and bad photos.

13. You are attending a training. What do you expect the speakers in the training to do?

a. Perform demonstration, modeling and practice.

b. Provides more time for question and answer sessions, discussion and sharing. 
c. Providing handouts, books or related papers.

d. Explain with many diagrams and graphs.

14. You just won the competition. For the development of your performance in the next competition, you want feedback from your coach. What kind of feedback do you expect?

a. Who uses a real example of what you did in his verbal explanation.

b. That uses detailed written descriptions so you can read and analyze carefully.

c. In the form of in-depth discussions in personal sharing sessions.

d. Which uses explanations in the form of graphs and diagrams.

15. There goes to a new cafe that you have never visited. what will you do?

a. Choose the menu that is familiar to you.

b. Ask the waiter / waitress or friend about the menu they recommend.

c. Choose by reading the description on the menu carefully.

d. Look around and choose based on what other people ordered or based on pictures in the menu list.

16. You will deliver an important presentation as a presenter at a conference. what will you do?

a. Make charts and graphs to help you remember exposure material.

b. Make pointers / keywords then practice doing presentations over and over again.

c. Make a written scenario about what you will talk about, then read it repeatedly.

d. Collect data and examples related to exposure. 